\title{
Constructing single-entry stem volume models for four economically important tree species of Greece
}

\author{
Panagiotis P. Koulelis*, Kostas Ioannidis
}

Institute of Mediterranean Forest Ecosystems, Athens, 11528, Greece

\begin{abstract}
Koulelis, P.P., IOANNIDIS, K., 2021. Constructing single-entry stem volume models for four economically important tree species of Greece. Folia Oecologica, 48 (2): 136-146.

Three different nonlinear regression models were tested for their ability to predict stem volume for economically important native tree species in Greece. The models were evaluated using adjusted $\mathrm{R}$ square $\left(\mathrm{A}_{\mathrm{dj}} \mathrm{R}_{\mathrm{sqq}}\right)$ root mean square error (RMSE) and Akaike information criterion (AICc), where necessary. In general, the quadratic polynomial and cubic polynomial models and the two-parameter power models fit the data well. Although the two-parameter power function fit best for fir, oak, and beech trees, the cubic polynomial model produced the best fit statistics for black pine. Making forest inventory estimates often involves predicting tree volumes from only the diameter at breast height $(\mathrm{DBH})$ and merchantable height. This study covers important gaps in fast and cost-effective methods for calculating the volume of tree species at national level. However, the increasing need for reliable estimates of inventory components and volume changes requires more accurate volume estimation techniques. Especially when those estimates concern the national inventory, those models must be validated using an entire range of age/diameter and site classes of each species before their extended use across the country to promote the sustainable use of forest resources.
\end{abstract}

\section{Keywords}

diameter at breast height, fit statistics, nonlinear regression, tree species, volume estimation

\section{Introduction}

Making forest inventory estimates often involves predicting tree volumes from only the diameter at breast height $(\mathrm{DBH})$ and/or merchantable height. This procedure is useful for forest managers because it is fast and requires few resources. The creation of stem volume models of individual tree species is a crucial topic in forestry, especially when those species are economically important to the forest sector. Most tree volume equations use tree height, diameter, and stem form (HuscH et al., 2003), or height and diameter (Schumacher and Hall, 1933), but (PEREZ and Kanninen, 2003) reported that even just one dimension, such as $\mathrm{DBH}$, can be used to construct a volume equation. Equations application varies across many tree species and countries. More recently, (LEE et al., 2017) estimated the stem volume of many species of pine and larch (Pinus densiflora, Pinus koraiensis, and Larix kaempferi) using one-entry and two-entry volume equations after validation. BRUNORI et al. (2017) developed a tool to predict woody biomass and tree component volume for the olive tree to be used, as they reported, for

\footnotetext{
*Corresponding author: e-mail: pkoulelis@fria.gr, ioko@fria.gr 
agricultural and environmental purposes. STOLARIKova et al. (2014) tested many equations to find the most suitable to calculate lime (Tilia cordata Mill.) volumes, aiming to improve the current destructive, costly, time-consuming volume model. LiU et al. (2019) proposed a new non-destructive, low-cost, efficient method for calculating tree volume models with high precision; they used only the electronic theodolite to create volume models for Platycladus orientalis, Larix principis-rupprechtii, and Populus spp in China. Similar methodologies were used in plantations and for young trees. For instance, (BJARNADOTTIR et al., 2007) constructed single-tree biomass and volume functions for young larch plantations in Iceland using the diameter at a height of $0.5 \mathrm{~m}$ and tree height as independent variables. With advances in science and technology, new methods to measure volumes of tree stands have been created. Optical electronic total stations, photogrammetry technology, three-dimensional laser scanning technology, unmanned aerial systems, and other non-contact measurement methods have been introduced in the field of forestry (LiU et al., 2019).

The development of a new national forest inventory (NFI) is under negotiation in Greece, for which a costeffective tool to measure tree volume could be used. Reliable estimations of inventory components and volume changes are always required by forest managers and scientists. The present, outdated NFI, which was completed in 1992, had no accurate models to use like the above. Moreover, Greek forest management (silviculture) and harvesting procedures have technology restrictions due to their high altitudes, morphology, and slopes and their fairly high logging and transportation costs (due to the location of forests, distance of roads, etc.), (TsitsonI, 2016). All these factors impact the availability of wood and the national forest industry sector. Cost-effective, less time-consuming, flexible tools are essential to take these measurements in forests. The literature confirms that stem volume models are valuable and flexible as management tools. KITIKIDOU et al. (2017) developed a single-entry volume model for Pinus brutia, using data from eighteen permanent experimental plots in the context of a research project on the recovery of degraded coniferous forests. The researchers decided that the quadratic model excelled over other regression models using simple statistical tests. Apatsidis and SifaKis (1999) proposed stem volume (barked and unbarked) models and other dendrometric equations for the most common tree species in Greece (oak, beech, fir, black pine, Aleppo pine, Calabrian pine, Scotch pine, spruce and cypress). Most of the above models were calculated using measurements from the ground, using relascope and tree measurements relative equipment (a caliper or a diameter tape and Blume-Leiss and/or Haga altimeters $(0.1 \mathrm{~m})$ for height measurements), applying trigonometric calculations, without measurements on fallen trees, and many experienced foresters in Greece state that these equations are accurate. Non-destructive observation is a promising methodology to establish tree volume tables, especially in areas where cutting is prohibited or restricted and there is therefore a lack of tree volume tables. Apatsidis' mod- els can easily calculate the volume that a forest manager or a researcher would want. These models can be used not just locally but at a national level.

The main purpose of this study is to propose and validate additional single-entry volume functions that could be easily tested nationally as tools for forest management or to take a national forest inventory, which is a subject currently under consideration in Greece. More specifically, this study used statistics to simplify the older models (APATSIDIS and SIFAKIS, 1999) and develop individual stem volume-diameter nonlinear equations for $A b$ ies borisii-regis Mattf. (Bulgarian fir), Quercus frainetto Ten. (Hungarian or Italian oak), Fagus sylvatica L. (European beech), and Pinus nigra Ten. (black pine). Despite the ecological and economic importance of the above species in Greece, there is still a knowledge gap about their growth and yield properties. In particular, single-entry volume models able to calculate unbarked or barked stem volume in less time and with precision, using only the DBH are needed. Their role is to improve the knowledge of the forest and solve problems when management procedures are too expensive and time consuming (e.g. many trees in the stand to be measured or large forest heterogeneity). Further testing of larger datasets for future use in management plans or for the development of the new revised national forest inventory, is surely a priority before their implementation at national level.

\section{Materials and methods}

Sample trees for three out of the four species, Bulgarian fir, European beech, and Hungarian oak, were selected from the three permanent monitoring ICP plots in Greece (ICP Forests Level II plots) (International Co-operative Programme on Assessment and Monitoring of Air Pollution Effects on Forests), (ICP-Forests.net, 2017), and samples of black pine were selected from a random plot established in the Peloponnese. According to DE VRIES et al., 2014, growth measurements of the above-mentioned species were taken within ICP Forest Level II plots (Fig. 1) using a common protocol across all the participating countries. Bulgarian fir is a tree species endemic to the Balkan Peninsula and is found in Greece, Albania, Bulgaria, and North Macedonia (CAudullo and Tinner, 2016). Fagus sylvatica L., or European beech, is one of the most important and widespread broadleaved trees in Europe. It is a large deciduous tree that can maintain its high growth rate until late maturity. Its natural range extends from southern Scandinavia to Sicily, from Spain in the west to northwest Turkey in the east (DuRRANT et al., 2016). Quercus frainetto or Hungarian oak is a species native to Balkan Peninsula, and also present in South Italy and North-West Turkey (MAuri et al., 2016). The later methodology was implemented for black pine.

Pinus nigra J.F. Arnold, known as European black pine or black pine, is a fast-growing conifer with a wide but fragmented distribution across Europe and Asia Minor, predominantly in mountain areas. Black pine presently covers more than 3.5 million hectares, making it 


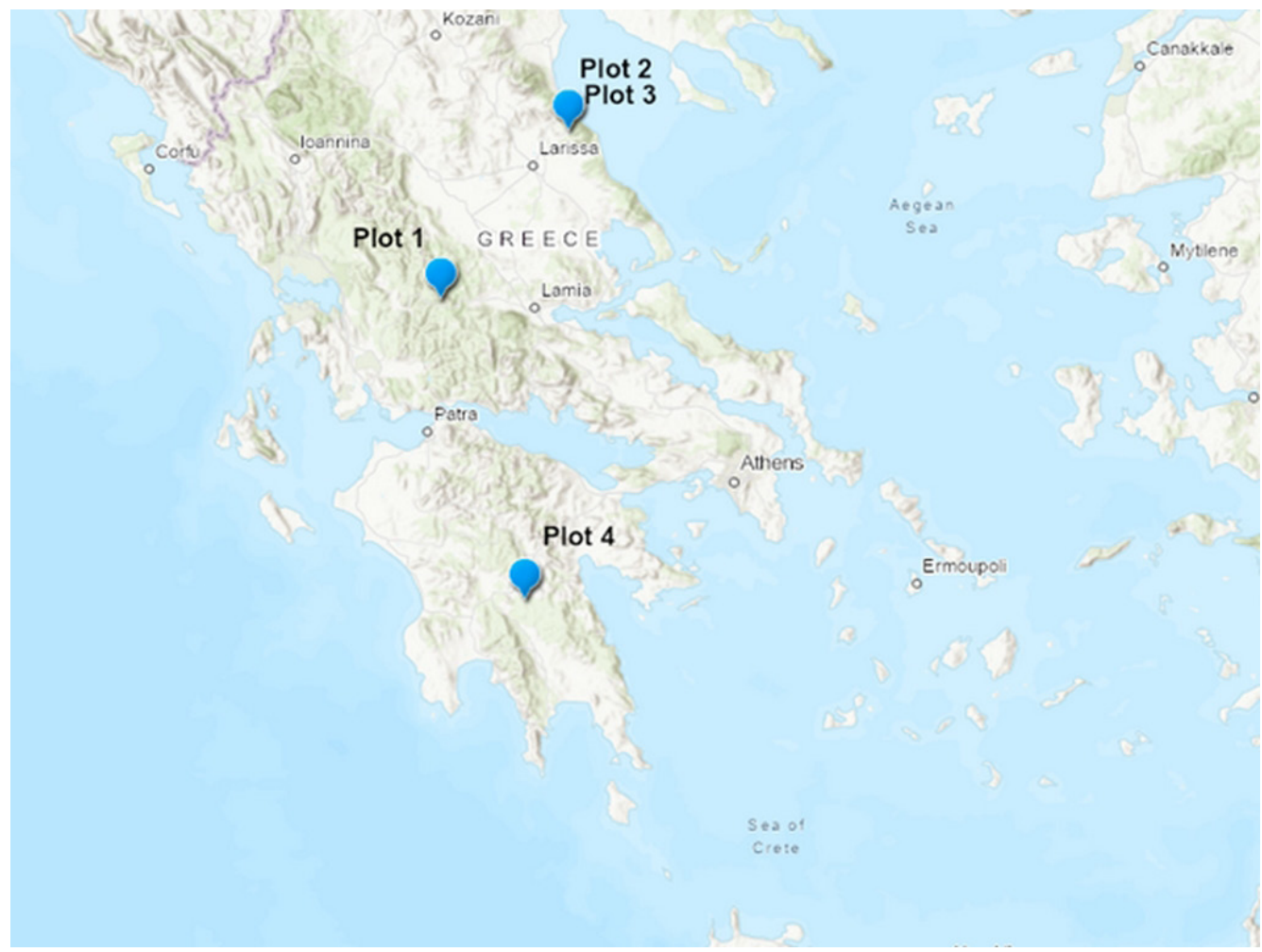

Fig. 1. Location of study areas (powered by esri, @esri.com).

one of the most widespread conifer species in the Balkans and Asia Minor (ENESCU et al., 2016). In Greece, black pine is one of the most timber productive species, together with fir, oak, and beech. Black pine trees were sampled from natural monospecific forest stands in Skirtida forest, located in the southern part of the Peloponnese. These black pine forests are growing on the margins of the species' expansion in Greece (IOANNIDIS et al., 2019) and Europe (EUFOrGEN, 2009). All the plots' characteristics are presented in Table 1.

Harmonized methods for sampling and analysis were followed according to ICP procedures, aiming for the relevant monitoring (DobBertin and Neumann, 2010) the basic periodic measurements $(\mathrm{DBH}$, tree height, heightto-crown base, removals, and mortality) were taken at approximately five-year intervals. All trees were marked with labels and numbers so that future surveys could use the same trees. Three common nonlinear functions were used to determine the appropriate tree volume model. More specifically, quadratic polynomial, cubic polynomial, and two-parameter power models were tested for their ability to predict barked and unbarked stem volume. The

Table 1. Characteristics of the four examined species

\begin{tabular}{|c|c|c|c|c|c|c|}
\hline $\begin{array}{l}\text { Plot } \\
\text { No }\end{array}$ & Latitude & Longitude & Aspect & $\begin{array}{l}\text { Area } \\
\left(\mathrm{m}^{2}\right)\end{array}$ & $\begin{array}{c}\text { Age } \\
\text { (years) }\end{array}$ & $\begin{array}{c}\text { Number of } \\
\text { trees }\end{array}$ \\
\hline $\begin{array}{c}1 \text { (Fir) } \\
\text { Tymfristos } \\
\text { Mountain }\end{array}$ & $38^{\circ} 52^{\prime} 29^{\prime}$ & $21^{\circ} 52^{\prime} 02^{\prime}$ & $\mathrm{N}$ & 2.990 & 110 & 89 \\
\hline $\begin{array}{c}2(\text { Oak }) \\
\text { Ossa Mountain }\end{array}$ & $39^{\circ} 47^{\prime} 10^{\prime \prime}$ & $22^{\circ} 47^{\prime} 40^{\prime \prime}$ & NE & 2.624 & 95 & 197 \\
\hline $\begin{array}{c}3(\text { Beech }) \\
\text { Ossa Mountain }\end{array}$ & $39^{\circ} 47^{\prime} 52^{\prime \prime}$ & $22^{\circ} 46^{\prime} 37^{\prime}$ & $\mathrm{NE}$ & 2.733 & 130 & 110 \\
\hline $\begin{array}{l}4 \text { (Black pine) } \\
\text { N. Parnonas } \\
\text { Mountain }\end{array}$ & $37^{\circ} 20^{\prime} 28^{\prime}$ & $22^{\circ} 20^{\prime} 60^{\prime \prime}$ & $\mathrm{N}$ & 3.150 & 39 & 117 \\
\hline
\end{tabular}


selection of these models was based mostly on examination of the volume-diameter relationship, as observed by plotting stem volume against DBH for the four tree species included in this study (Table 2).

Table 2. Stem volume functions selected for comparison

\begin{tabular}{ccc}
\hline No & Name & Function \\
\hline 1 & Polynomial, Quadratic & $y=y_{0}+a x+b x^{2}$ \\
2 & Polynomial, Cubic & $y=y_{0}+a x+b x^{2}+c x^{3}$ \\
3 & Power, 2 Parameter & $y=a x^{b}$ \\
\hline
\end{tabular}

The model construction was based on the data of 2006 regarding all tree species. The unbarked and barked volume values were estimated using the (APATSIDIS and SIFAKIS, 1999) models for each species, as presented below:

Unbarked stem volume for fir

$V_{u}=6.3661 * 10^{-5} * d b h^{1.7681} * h^{1.0607}$

Barked stem volume for fir

$V_{b}=0.02406+1.101 * V_{u}$

Unbarked stem volume for oak

$V_{u}=2.5182 * 10^{-5} * d b h^{0.7903} * h^{1.1819}$

Barked stem volume for oak

$V_{b}=0.01631+1.1347 * V_{u}$

Unbarked stem volume for beech

$V_{u}=4.08639 * 10^{-5} * d b h^{1.9858} * h^{0.9478}$

Barked stem volume for beech

$V_{b}=0.0041+1.05955 * V_{u}$

Unbarked stem volume for black pine
$V_{u}=3.9172327 * 10^{-5} * d b h^{1.884915} * h^{1.043285}(7)$

Barked stem volume for black pine

$V_{b}=0.0217237+1.177424 * V_{u}$

The evaluation of the diameter and volume models was based on the adjusted coefficient of determination $\left(\mathrm{R}_{\text {adj }}^{2}\right)$ and the root mean square error (RMSE) at significance level $\mathrm{p}<0.05$. The models were validated based on an independent test sample (1/3 of the actual values), which tested the accuracy of the model by checking the distribution of errors.

Where the differences between $\mathrm{R}_{\text {adj; }}^{2}$ and RMSE were very small, the Akaike information criterion (AICc) was used to select the best-fitting model. The AICc was first developed by AKAIKE (1973) to compare different models on a given outcome. When a model involving q parameters is fitted to data, the criterion is defined as:

$$
A I C=-2 \mathrm{~L}_{q}+2 q \text {, }
$$

where $\mathrm{L}_{\mathrm{q}}$ is the maximized log likelihood.

$\mathrm{AIC}_{\mathrm{c}}$ (HuRvich and TSAI, 1989) is more suitable for small data samples.

$$
A I C_{C}=A I C+\frac{2 K(K+1)}{n-K-1}
$$

where $\mathrm{K}$ is the number of estimable parameters (degrees of freedom). The best model is the model with the lowest

(3) $\mathrm{AIC}_{\mathrm{c}}$ (or AIC) score.

\section{Results and discussion}

(5) The results of the applied models (the parameter estimations and their errors, the adjusted coefficients of determination, and the root mean square errors) as fit statistics tests for fir, oak, beech, and black pine are presented in detail in Tables 3, 4, 5, and 6 respectively.

\begin{tabular}{|c|c|c|c|c|c|}
\hline $\begin{array}{c}\text { Fir } \\
\text { (unbarked) } \\
\text { Function }\end{array}$ & $\begin{array}{l}\text { a (error) } \\
(p)\end{array}$ & $\begin{array}{l}\mathrm{b} \text { (error) } \\
(\mathrm{p})\end{array}$ & $\begin{array}{l}\text { c (error) } \\
\text { (p) }\end{array}$ & $\mathrm{A}_{\mathrm{dj}} \mathrm{R}_{\mathrm{sqr}}$ & RMSE \\
\hline 1 & $\begin{array}{c}-0.0057(0.005) \\
(0.3381)\end{array}$ & $\begin{array}{c}-0.0011(0.007) \\
<0.0001\end{array}$ & - & 0.9843 & 0.173 \\
\hline 2 & $\begin{array}{c}-0.0363(0.019) \\
(0.0657)\end{array}$ & $\begin{array}{c}0.0019(0.000) \\
(0.0004)\end{array}$ & $\begin{array}{c}0.00006(0.000) \\
(0.1024)\end{array}$ & 0.9848 & 0.170 \\
\hline 3 & $\begin{array}{l}0.0004(0.000) \\
\quad(<0.0001)\end{array}$ & $\begin{array}{c}2.2007(0.049) \\
(<0.0001)\end{array}$ & - & 0.9830 & 0.180 \\
\hline \multicolumn{6}{|l|}{$\begin{array}{c}\text { Fir } \\
\text { (barked) } \\
\text { Function }\end{array}$} \\
\hline 1 & $\begin{array}{c}-0.0062(0.006) \\
(0.3381)\end{array}$ & $\begin{array}{c}0.0012(0.000) \\
(<0.0001)\end{array}$ & - & 0.9843 & 0.190 \\
\hline 2 & $\begin{array}{c}-0.0399(0.0213) \\
(0.0657)\end{array}$ & $\begin{array}{c}0.0021(0.000) \\
(0.0004)\end{array}$ & $\begin{array}{c}0.0007(0.00) \\
(0.1024)\end{array}$ & 0.9848 & 0.187 \\
\hline 3 & $\begin{array}{c}0.000(0.00) \\
(<0.0001)\end{array}$ & $\begin{array}{c}2.1783(0.048) \\
\quad(<0.0001)\end{array}$ & - & 0.9834 & 0.196 \\
\hline
\end{tabular}

Table 3. Parameter estimations for nonlinear models regarding fir 
Table 4. Parameter estimations for nonlinear models regarding oak

\begin{tabular}{|c|c|c|c|c|c|c|}
\hline $\begin{array}{c}\text { Oak } \\
\text { (unbarked) } \\
\text { Function }\end{array}$ & $\begin{array}{l}\text { a (error) } \\
(p)\end{array}$ & $\begin{array}{l}\mathrm{b} \text { (error) } \\
(\mathrm{p})\end{array}$ & $\begin{array}{l}\text { c (error) } \\
\text { (p) }\end{array}$ & $A_{d j} R_{s q r}$ & RMSE & $\mathrm{AICc}$ \\
\hline 1 & $\begin{array}{c}0.0007(0.001) \\
(0.9953)\end{array}$ & $\begin{array}{c}0.0007(0.000) \\
(<0.0001)\end{array}$ & - & 0.9895 & 0.036 & \\
\hline 2 & $\begin{array}{c}-0.0096(0.004) \\
(0.0312)\end{array}$ & $\begin{array}{l}0.0011(0.000) \\
\quad<0.0001\end{array}$ & $\begin{array}{l}0.0005(0.000) \\
\quad(0.0247)\end{array}$ & 0.9898 & 0.036 & -970.8970 \\
\hline 3 & $\begin{array}{l}0.0003(0.000) \\
\quad(<0.0001)\end{array}$ & $\begin{array}{l}2.1732(0.028) \\
\quad(<0.0001)\end{array}$ & - & 0.9784 & 0.039 & -999.4958 \\
\hline \multicolumn{7}{|l|}{$\begin{array}{c}\text { Oak } \\
\text { (barked) } \\
\text { Function }\end{array}$} \\
\hline 1 & $\begin{array}{c}0.008(0.001) \\
(0.9953)\end{array}$ & $\begin{array}{c}0.0007(0.000) \\
(<0.0001)\end{array}$ & - & 0.9895 & 0.041 & \\
\hline 2 & $\begin{array}{c}-0.0109(0.005) \\
(0.0312)\end{array}$ & $\begin{array}{l}0.0012(0.000) \\
\quad<0.0001\end{array}$ & $\begin{array}{l}0.0006(0.000) \\
\quad(0.0247)\end{array}$ & 0.9898 & 0.041 & -948.6069 \\
\hline 3 & $\begin{array}{c}0.0005(0.000) \\
(<0.0001)\end{array}$ & $\begin{array}{c}2.1067(0.00) \\
(<0.0001)\end{array}$ & - & 0.9887 & 0.042 & -961.5666 \\
\hline
\end{tabular}

Table 5. Parameter estimations for nonlinear models regarding beech

\begin{tabular}{|c|c|c|c|c|c|}
\hline $\begin{array}{c}\text { Beech } \\
\text { (unbarked) } \\
\text { Function }\end{array}$ & $\begin{array}{l}\text { a (error) } \\
(p)\end{array}$ & $\begin{array}{l}\mathrm{b} \text { (error) } \\
(\mathrm{p})\end{array}$ & $\begin{array}{c}\text { c (error) } \\
\text { (p) }\end{array}$ & $A_{d j} R_{s q r}$ & RMSE \\
\hline 1 & $\begin{array}{c}-0.0056(0.006) \\
(0.4083)\end{array}$ & $\begin{array}{c}0.0011(0.000) \\
(<0.0001)\end{array}$ & - & 0.9757 & 0.134 \\
\hline 2 & $\begin{array}{c}0.0087(0.020) \\
(0.6655)\end{array}$ & $\begin{array}{c}0.0007(0.000) \\
(0.2306)\end{array}$ & $\begin{array}{c}0.0003(0.000) \\
0.4506\end{array}$ & 0.9755 & 0.135 \\
\hline 3 & $\begin{array}{l}0.0005(0.000) \\
\quad<0.0001\end{array}$ & $\begin{array}{c}2.1680(0.041) \\
\quad(<0.0001)\end{array}$ & & 0.9759 & 0.134 \\
\hline \multicolumn{6}{|l|}{$\begin{array}{c}\text { Beech } \\
\text { (barked) } \\
\text { Function }\end{array}$} \\
\hline 1 & $\begin{array}{c}-0.0060(0.007) \\
(0.4083)\end{array}$ & $\begin{array}{c}0.0011(0.000) \\
(<0.0001)\end{array}$ & - & 0.975 & 0.142 \\
\hline 2 & $\begin{array}{c}0.0092(0.021) \\
(0.6655)\end{array}$ & $\begin{array}{c}0.0007(0.000) \\
(0.2306)\end{array}$ & $\begin{array}{c}0.0003(0.000) \\
(0.4506)\end{array}$ & 0.9755 & 0.143 \\
\hline 3 & $\begin{array}{c}0.0005(0.000) \\
<0.0001\end{array}$ & $\begin{array}{c}2.1630(0.0415) \\
<0.0001\end{array}$ & - & 0.9759 & 0.142 \\
\hline
\end{tabular}

The adjusted coefficient of determination for all cases ranged within high and acceptable intervals: 0.9830 to 0.9848 for fir, 0.9755 to 0.9759 for oak, 0.9874 to 0.9898 for beech, and 0.9694 to 0.9704 for black pine, without differentiation between barked and unbarked stem volume data. In addition, all the parameters of the functions were significant $(\mathrm{p}<0.005)$ in the two-parameter power function for fir, oak, and beech, while they were significant for black pine in the cubic polynomial model. Moreover, RMSE values were very low, varying from 0.170 to 0.196 for fir, 0.134 to 0.143 for oak, 0.036 to 0.042 for beech, and
0.041 to 0.049 for black pine, presenting slightly smaller values for unbarked than for barked stem volume data.

Based on these results and the criteria previously mentioned regarding model selection at the first stage of the analysis, the two-parameter power function was chosen as the best fitted for fir, oak and beech, while the cubic polynomial function was chosen for black pine.

In the case of fir, although the first two models presented a higher adjusted coefficient of determination $\left(\mathrm{R}_{\text {adj }}^{2}>0.98\right)$ as well as a lower RMSE, the two-parameter power function was selected as the best model to predict 
Table 6. Parameter estimations for nonlinear regarding black pine

\begin{tabular}{|c|c|c|c|c|c|c|}
\hline $\begin{array}{c}\text { Black pine } \\
\text { (unbarked) } \\
\text { Function }\end{array}$ & $\begin{array}{l}\text { a (error) } \\
(p)\end{array}$ & $\begin{array}{l}\mathrm{b} \text { (error) } \\
(\mathrm{p})\end{array}$ & $\begin{array}{l}\text { c (error) } \\
\text { (p) }\end{array}$ & $A_{d j} R_{s q r}$ & RMSE & $\mathrm{AICc}$ \\
\hline 1 & $\begin{array}{c}0.0008(0.0066) \\
(0.6158)\end{array}$ & $\begin{array}{l}0.0008(0.000) \\
(<0.0001)\end{array}$ & - & 0.9695 & 0.042 & -756.2711 \\
\hline 2 & $\begin{array}{c}-0.0999(0.0425) \\
(0.0203)\end{array}$ & $\begin{array}{l}0.0035(0.0013) \\
\quad<0.0069\end{array}$ & $\begin{array}{l}0.0002(0.000) \\
\quad(0.0328)\end{array}$ & 0.9704 & 0.041 & -758.8239 \\
\hline 3 & $\begin{array}{l}0.0002(0.000) \\
\quad(<0.0001)\end{array}$ & $\begin{array}{l}2.3062(0.0402) \\
\quad(<0.0001)\end{array}$ & - & 0.9694 & 0.042 & -757.2553 \\
\hline \multicolumn{7}{|l|}{$\begin{array}{c}\text { Black pine } \\
\text { (barked) } \\
\text { Function }\end{array}$} \\
\hline 1 & $\begin{array}{c}-0.0110(0.007) \\
(0.166)\end{array}$ & $\begin{array}{c}0.0009(0.0078) \\
(<0.0001)\end{array}$ & - & 0.9695 & 0.049 & -718.1739 \\
\hline 2 & $\begin{array}{c}-0.1176(0.05) \\
(0.0203)\end{array}$ & $\begin{array}{l}0.0041(0.0015) \\
\quad(0.0068)\end{array}$ & $\begin{array}{l}0.0003(0.000) \\
\quad(0.0328)\end{array}$ & 0.9704 & 0.048 & -720.7269 \\
\hline 3 & $\begin{array}{l}0.0003(0.000) \\
(<0.0001)\end{array}$ & $\begin{array}{l}2.2454(0.039) \\
(<0.0001)\end{array}$ & - & 0.9696 & 0.048 & -719.6385 \\
\hline
\end{tabular}

volume based on DBH because of the lower significance level of the function parameters $(p<0.0001)$. In the case of oak, the two-parameter power function was selected because it had a higher adjusted coefficient of determination $\left(\mathrm{R}_{\text {adj }}^{2}=0.9759\right)$, the lowest RMSE, and significant levels for the function parameters $(\mathrm{p}<0.0001)$. The cases of beech and black pine had some similarities to that of fir. The first two tested models presented higher adjusted coefficients of determination, $\mathrm{R}_{\text {adj }}^{2}>0.98$ for beech and $\mathrm{R}_{\text {adj }}^{2}>0.96$ for black pine. For the same equations in beech, RMSE was also lower. The function was therefore selected based on the lowest significance level and the lowest value of the AICc estimator. The two-parameter power function was selected for beech (for unbarked volume $\mathrm{p}<0.0001$, $\mathrm{AICc}=-999.4958, \mathrm{R}^{2}{ }_{\text {adj }}=0.9874, \mathrm{RMSE}=0.039$; for barked volume $\mathrm{p}<0.0001, \mathrm{AICc}=-961.5666, \mathrm{R}^{2}{ }_{\text {adj }}=0$. 9887 , RMSE $=0.042$ ), while the cubic polynomial function was selected for black pine (for unbarked volume $\mathrm{p}<0.0203$ and $\mathrm{p}<0.0069$ for $\mathrm{a}$ and $\mathrm{b}$ coefficients, AICc $=-758.8239, \mathrm{R}^{2}=0.9704, \mathrm{RMSE}=0.041$; for barked volume $\mathrm{p}<0.0203$ and $\mathrm{p}<0.0068$ for $\mathrm{a}$ and $\mathrm{b}$ coefficients, $\mathrm{AICc}=-720.7269, \mathrm{R}_{\text {adj }}^{2}=0.9704, \mathrm{RMSE}=0.048$ ).

Figure 2 presents the plots of the unbarked and barked stem volumes against DBH for fir, using the best fitted two-power parameter function as well as the $95 \%$ confidence and prediction band. Figure 3 presents the plots of the unbarked and barked stem volumes against $\mathrm{DBH}$ for oak, produced by their best fitted functions. Figure 4 presents the plots of the unbarked and barked stem volumes for beech, and Fig. 5 presents the same plots for black pine. In the latter figures, only a few values (one for oak, two for beech, and one for black pine) were outside the region of certainty in predicting ( $95 \%$ prediction band). Moreover, the residual analysis described by the bar charts of the residuals (suggestively Fig. 6 regarding the fir) shows across all the observations, that the points appear to be randomly spread out around 0 , with no discernible nonlinear trend or changes in variability, indicating that variances are independent of the observations. Regarding validation, as described in the materials and method section, an independent sample of the measurements whose values were not used in model building was selected for every species. In every case, the selected model fits the training dataset and the validation dataset. Figure 7 for example presents the plot of regression, including the values of the independent sample regarding fir.

This study shows that representative volume equations exist for major timber-productive tree species in Greece. In Greece's national inventory, the barked and unbarked stem volume of the studied species may be estimated using volume equations (APATSIDIS and SIFAKIS, 1999). We present some simpler equations that are consistent with those previously reported in Greek forestry literature (APATSIDIS and SIFAKIS, 1999). The independent variable of every stem volume equation was $\mathrm{DBH}$, and the equations used various mathematical combinations, involving several coefficients. Similar equations that use DBH as an independent variable in several formalities have been used by other researchers to calculate tree volume or even tree biomass (DIK, 1984; HARDING and GRIGAL, 1985; PICARD et al., 2012; VIBRANS et al., 2015). Most volume equations vary in coefficient numbers or in the exponents that the dependent variables are raised (HENRY et al., 2013; VIBRANS et al., 2015; LeE et al., 2017). All these nonlinear models make possible accurate fitting and valid prediction of volumes (Henry et al., 2013; ZuUR et al., 2009). As stated by several researchers, even if the predicted stem volume estimates vary according to the applied equation which some differentiate from others (i.e., equations reported by SCHELHAAS et al., 2002 and LAASASENAHO, 1982), when they are used in different forms or with more explanatory variables, they make predictions consistent with the mod- 

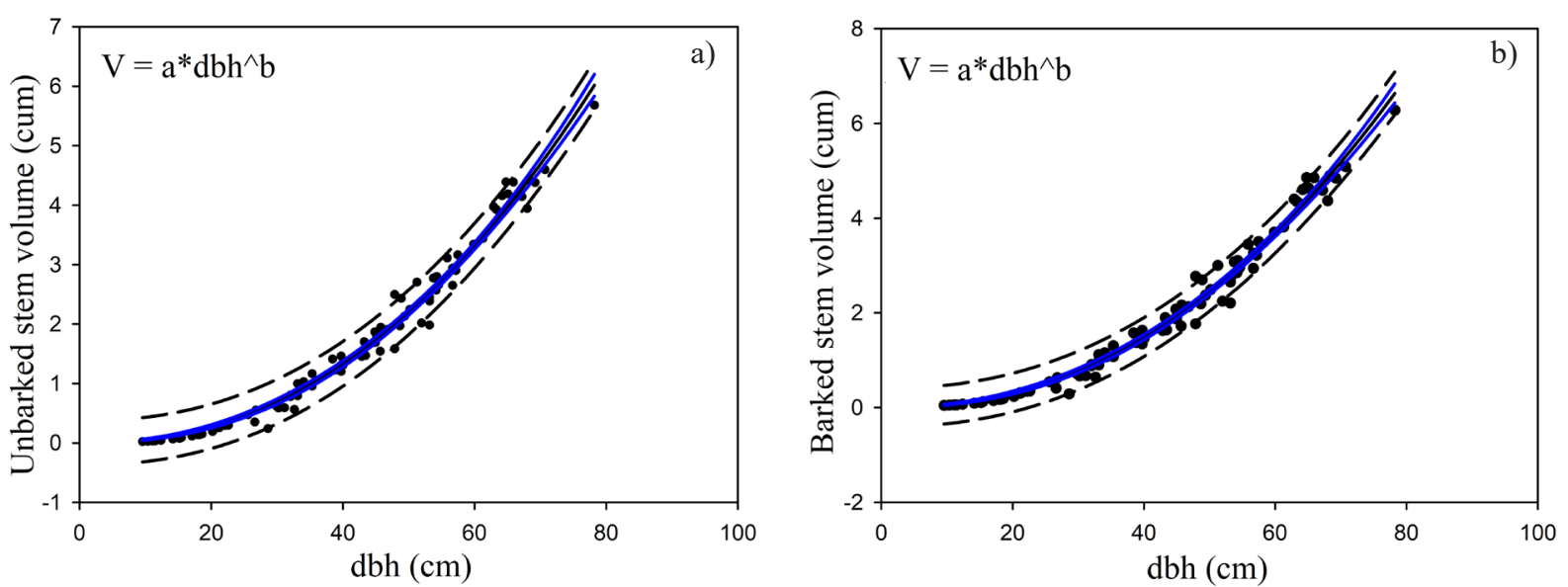

Fig. 2. Plot of the a) unbarked and b) barked stem volume against DBH for fir. The plot was produced by the best fitted power 2 parameter function. 95\% Confidence Band (solid line); 95\% Prediction Band (dashed line).
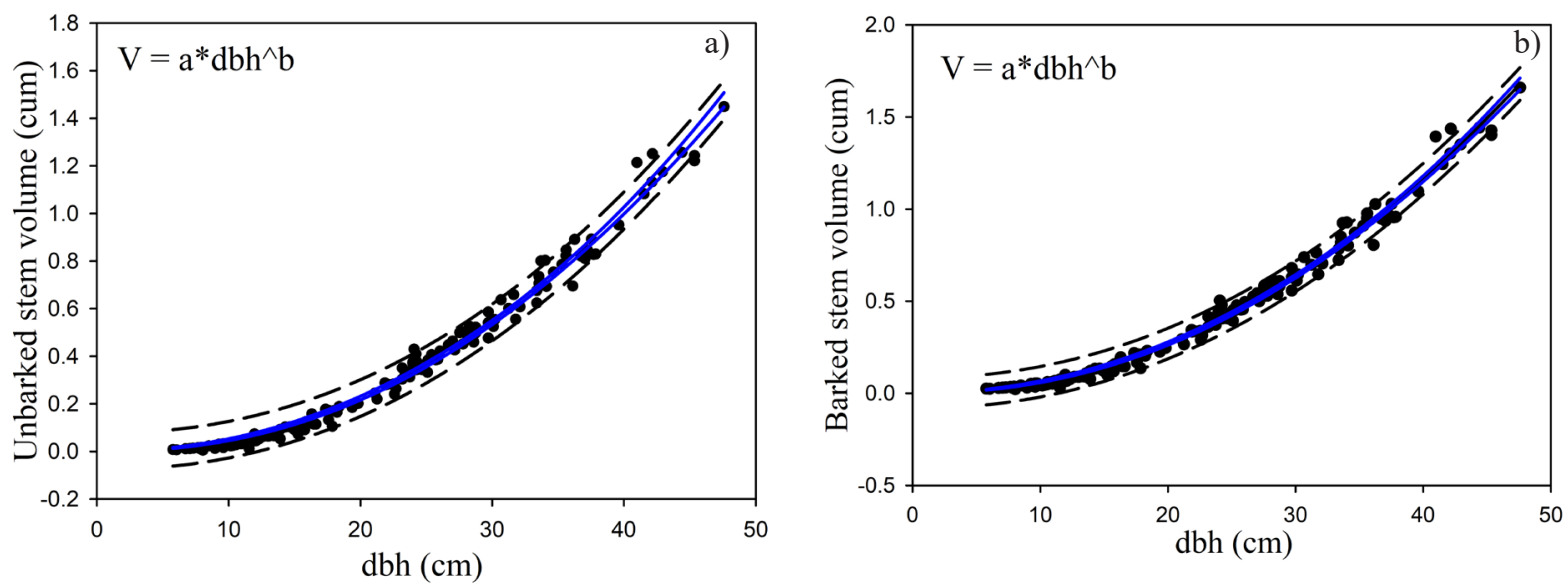

Fig. 3. Plot of the a) unbarked and b) barked stem volume against DBH for oak. The plot was produced by the best fitted power 2 parameter function. 95\% Confidence Band (solid line); 95\% Prediction Band (dashed line).
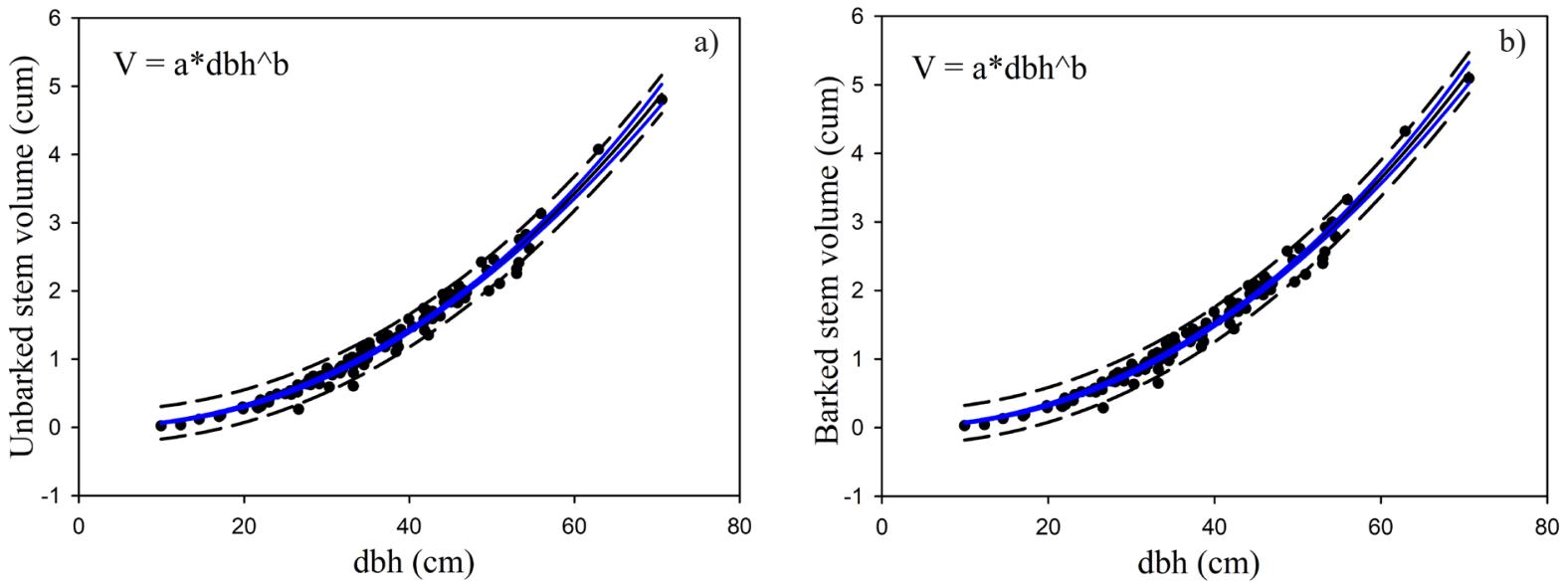

Fig. 4. Plot of the a) unbarked and b) barked stem volume against DBH for beech. The plot was produced by the best fitted power 2 parameter function. 95\% Confidence Band (solid line); 95\% Prediction Band (dashed line). 

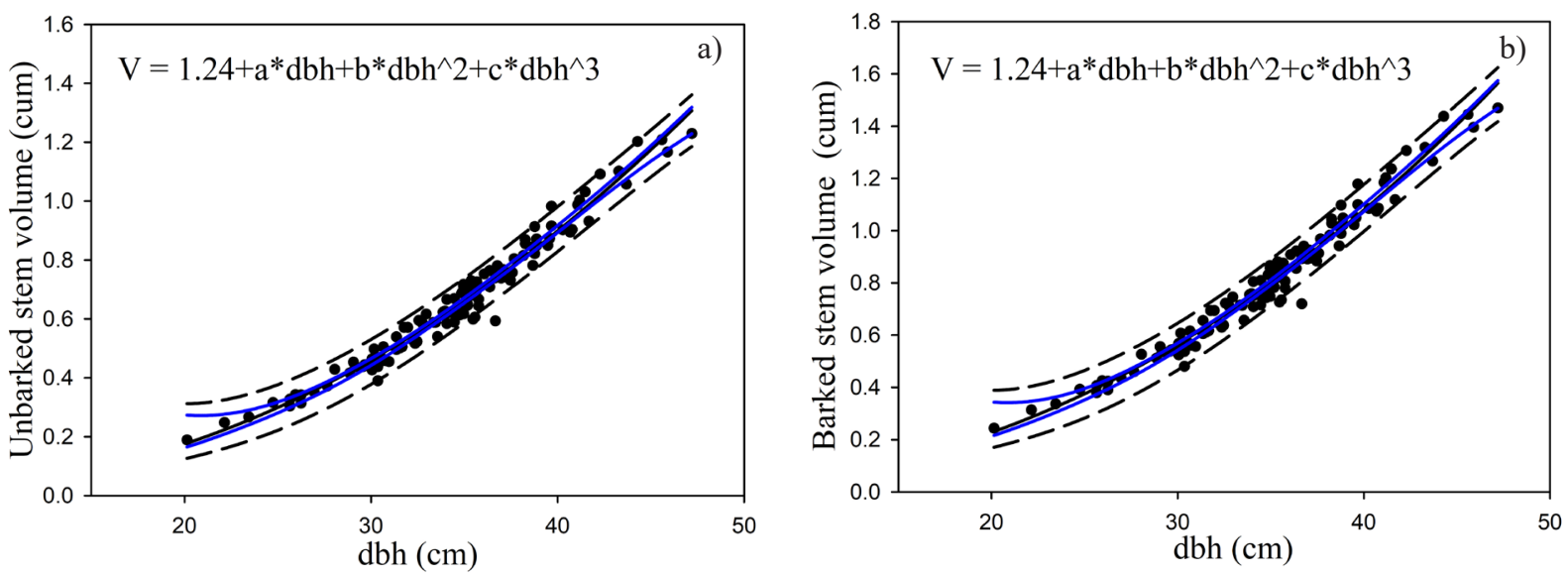

Fig. 5. Plot of the a) unbarked and b) barked stem volume against DBH for black pine. The plot was produced by the best fitted polynomial cubic function. 95\% Confidence Band (solid line); 95\% Prediction Band (dashed line).


Fig. 6. Relationship between the residual a) unbarked and b) barked stem volume (actual values) for power 2 parameter model and dbh regarding fir.

els of other authors and produce relatively consistent stem volume estimates (ZIANIS et al., 2005).

Our evaluation confirms and suggests the presented results. SpANOs et al. (2015) reported serious deficiencies in the information system and statistical forestry in all directions (natural environment, establishment of forest productivity, forest inventory, forest ownership and land use, forest management, forestry, etc.), leading to weakness in design development and in the mobilization of resources and potential. Even under the mentioned deficiencies, of production, the importance of the examined species as productive species of the national forest sector must be emphasized. KouleLIS et al. (2019) reported, taking into account official national sources, that oak occupies the largest range of Greek industrial forests and could contribute $5.56 \%$ of the country's total timber production and that beech is more common in the northwestern and eastern parts of the mainland and could contribute $20.05 \%$ of national production. Black pine is one of the most important timber species in Greece, forming forests in the mountains throughout most of the mainland and locally on large islands in the north (STRID and TAN, 1997) and could contribute $10.06 \%$ of national production. Finally, fir extends sparsely from the northern Peloponnese up to the northern border of the country and could contribute $30.23 \%$ of national production (KouleLIS, 2018). 


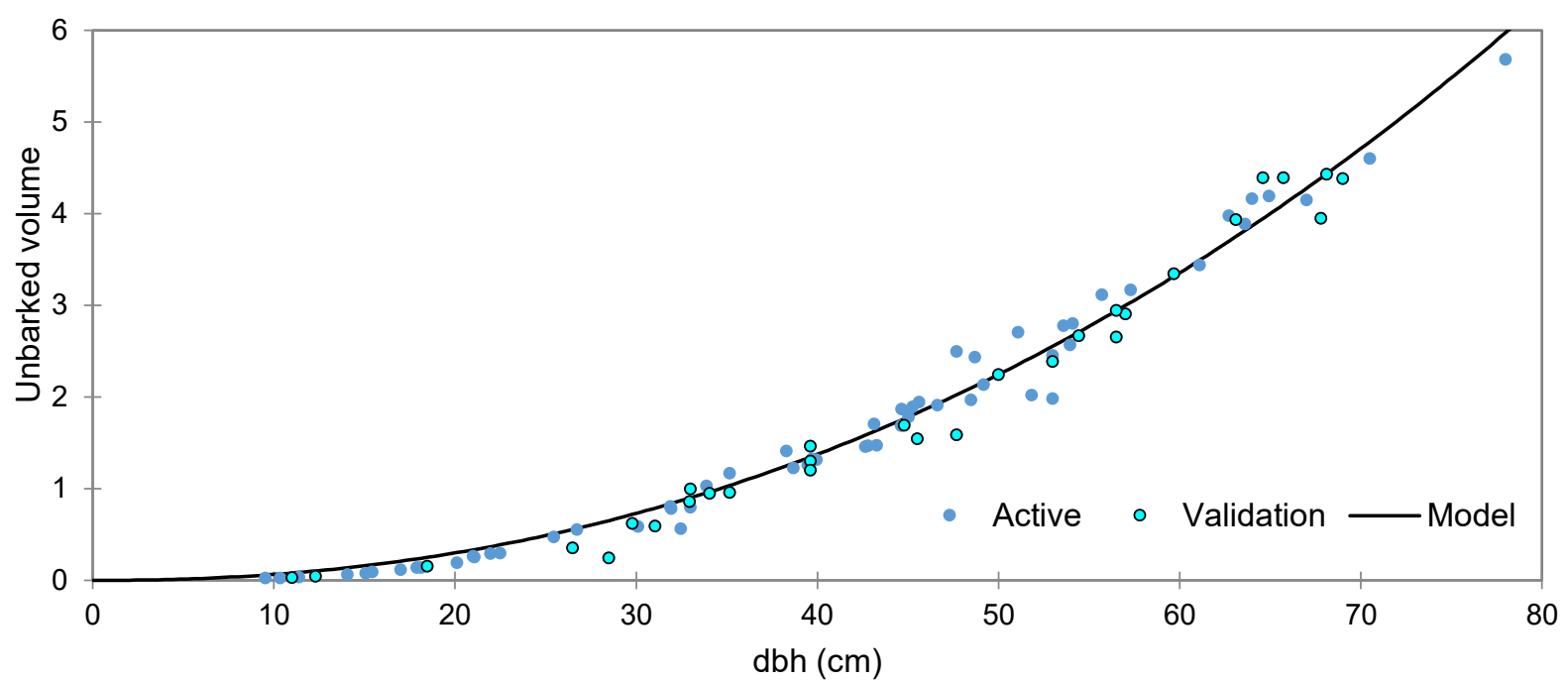

Fig. 7. Plot of the unbarked stem volume against DBH for fir produced by the best fitted power 2 parameter function with the actual (active) and validation dataset included.

\section{Conclusions}

These models may reveal higher accuracy when they are tested nationally in future studies. The equations selected for the four studied species are considered to be easily used, fast, effective ways of taking measurements.

This kind of nonlinear model is tested and often used globally to describe relationships between tree stand characteristics and tree stand biomass components: total aboveground, branches, foliage, and stem. In our study, the two-parameter power function was best-fitted for fir, oak, and beech, while the cubic polynomial function was best for black pine. This kind of model is lacking in Greece. Although, their generalization at national level could lead to a decrease in the accuracy, so their validation to larger samples is crucial.

In the field, foresters usually base their calculations on forest management plans and general formulas of volume, which aim to increase forest production and improve the quality and value of forest products (technical and industrial wood), but there are serious deficiencies in the information system. Moreover, based on the lack of functions sourced by destructive methods cutting down several sample trees, the potential implementation of the above equations at the national level could promote the multifunctional use of forests with less cost and less time, especially where modern systems of wood certification and sustainable forest management (SFM) are missing and where forest monitoring - under the possible new climate conditions - is crucial. The implementation of these equations is even more important for tree species that are economically important to Greece for their wood production; the equations are useful for calculating harvesting volumes and earnings and for promoting the market, as indicated in the study. Finally, after the selected equations are validated across the country, using an entire range of age/diameter and site classes of each species, they will be useful tools for creating a new forest inventory, a process that is now under negotiation and that must include biomass measure- ments. This inventory will also serve the secondary forest sector, which includes the use of woody biomass for energy and other purposes.

\section{Acknowledgements}

This research received funding from the Hellenic Ministry of Environment and Energy-Green Fund. (Decision number 148.3/2018), Innovative actions «Natural Environment \& innovative environmental actions 2018» (2019-2020).

\section{References}

Akaike, H., 1973. Information theory as an extension of the maximum likelihood principle. In Petrov, B.N., Csaki, F. (eds). Second international symposium on information theory. Tsahkadsor, Armenia, USSR September 2-8, 1971. Budapest: Akademiai Kiado, p. 267-281.

ApaTSIDIs, L., SifaKis, C., 1999. Electronic application (APSI) for the calculation of static and dynamic data of Beech, Fir, Oak, Spruce, Austrian, Aleppo, Brutian and Scots Pine and Cypress forest stands. User Manual. Athens, Greece: National Agricultural Research Foundation, Institute of Mediterranean Ecosystems \& Forest Products Technology. 32 p.

Bagnouls, F., Gaussen, H., 1957. Les climats biologiques et leur classification [The biological climates and their classification]. Annales de Géographie, 66 (355): 193-220. https://doi.org/10.3406/geo.1957.18273

Bjarnadottir, B., Inghammar, A-C., Brinker, M-M., SigURDSON, B.D., 2007. Single tree biomass and volume functions for young Siberian larch trees (Larix sibirica) in eastern Iceland. Icelandic Agricultural Sciences, 20: $125-135$.

Brunori, A., Dini, F., Cantini, C., Sala, G., La Mantia, T., Caruso, T., Marra, F.P., Trotta, C., Nasini, L., Regni, L., Proietti, P., 2017. Biomass and volume modeling in 
Olea europaea L. cv "Leccino". Trees - Structure and Function, 31 (6): 1859-1874. https://doi.org/10.1007/ s00468-017-1592-9.

Caudullo, G., Tinner, W., 2016. Abies - Circum-Mediterranean firs in Europe: distribution, habitat, usage and threats. In San-Miguel-Ayanz, J., De Rigo, D., Caudullo, G., Houston Durrant, T., Mauri, A. (eds). European atlas of forest tree species. Luxembourg: Publications Office of the European Union. 197 p.

De Vries, W., Dobbertin, M.H., Solberg, S., Van DobBEN, H.F., Schaub, M., 2014. Impacts of acid deposition, ozone exposure and weather conditions on forest ecosystems in Europe: an overview. Plant and Soil, 380: 1-45. https://doi.org/10.1007/s11104-014-2056-2

DIK, E.J., 1984. Estimating the wood volume of standing trees in forestry practice. Uitvoerig verslag/Rijksinstituut voor Onderzoek in de Bos-en Landschapsbouw "De Dorschkamp", 19, 1. Wageningen: De Dorschkamp. 114 p.

Dobbertin, M., Neumann, M., 2010. Tree growth. Manual Part V. In Manual on methods and criteria for harmonized sampling, assessment, monitoring and analysis of the effects of air pollution on forests. Hamburg: UNECE ICP Forests Programme Coordinating Centre. 29 p. [cit. 202011-27]. https://www.icp-forests.org/pdf/manual/2016/ ICP_Manual_2016_01_part05.pdf

Durrant, T., De Rigo, D., Caudullo, G., 2016. Fagus sylvatica in Europe: distribution, habitat, usage and threats. Extended summary of the chapter. In European atlas of forest tree species. Luxembourg: Publication Office of the European Union, p. 94-95. [cit. 2020-11-06]. https://forest.jrc.ec.europa.eu/media/atlas/Fagus_sylvatica.pdf

Enescu, C., De Rigo, D., Caudullo, G., Durrant, T., 2016. Pinus nigra in Europe: distribution, habitat, usage and threats. Extended summary of the chapter. In European atlas of forest tree species. Luxembourg: Publication Office of the European Union, p. 126-127. [cit. 2020-1106]. https://ies-ows.jrc.ec.europa.eu/efdac/download/Atlas/pdf/Pinus_nigra.pdf

Euforgen, 2009. Distribution map of Black pine (Pinus nigra). [cit. 2020-12-01]. www.euforgen.org

Harding, R.B., Grigal, D.F., 1985. Individual tree biomass estimation equations for plantation-grown white spruce in Northern Minnesota. Canadian Journal of Forest Research, 15: 738739.

Henry, M., Bombelli, A., Trotta, C., Alessandrini, A., BiRigazzi, L., Sola, G., Vieilledent, G., Santenoise, P., Longuetaud, F., Valentini, R., Picard, N., Saint-AnDRE, L., 2013. GlobAllomeTree: international platform for tree allometric equations to support volume, biomass and carbon assessment. iForest, 6: 326-330. https://doi. org/10.3832/ifor0901-006

Hurvich, C., Tsai, C-L., 1989. Regression and time series model selection in small samples. Biometrika, 76: 297293.

Husch, B., Beers, T.W., Kershaw, J.A., 2003. Forest mensuration. 4th ed. Hoboken (NJ): Wiley. 443 p.

ICP-forests.net, 2017. ICP Forests. [online]. [cit. 2020-1112]. http://icp-forests.net/

Ioannidis, K., Melliou, E., Magiatis, P., 2019. Highthroughput ${ }^{1} \mathrm{H}-\mathrm{Nuclear}$ Magnetic Resonance- based screening for the identification and quantification of heartwood diterpenic acids in four Black pine (Pinus nigra Arn.) marginal provenances in Greece. Molecules, 24 (19): 3603. https://doi.org/10.3390/molecules24193603

Kitikidou, K., Milios, E., Radoglou, K., 2017. Single-entry volume table for Pinus brutia in a planted peri-urban forest. Annals of Silvicultural Research, 41 (2): 74-79. https://doi.org/10.12899/asr-1437

Koulelis, P.P., Daskalakou, E.N., Michopoulos, P., 2018. Testing non-linear height-diameter functions for three native trees of Greece on ICP forests Level II plots. Austrian Journal of Forest Science, 4: 297-314.

Koulelis, P.P., Daskalakou, E.N., IoAnNidis, K.E., 2019. Impact of regional climatic conditions on tree growth on mainland Greece. Folia Oecologica, 46 (2): 127-136. https://doi.org/10.2478/foecol-2019-0015

LaAsasenaho, J., 1982. Taper curve and volume functions for pine, spruce and birch. Communicationes Instituti Forestalis Fenniae, 108. Helsinki: Finnish Forest Research Institute. 74 p.

Lee, D., SeO, Y., ChOI, J., 2017. Estimation and validation of stem volume equations for Pinus densiflora, Pinus koraiensis, and Larix kaempferi in South Korea. Forest Science and Technology, 13 (2): 77-82. https://doi.org/10.10 80/21580103.2017.1315963

Liu, J., Feng, Z., Mannan, A., Khan, T.U., Cheng, Z., 2019. Comparing non-destructive methods to estimate volume of three tree taxa in Beijing, China. Forests, 10 (2): 1-15. https://doi.org/10.3390/f10020092

Mauri, A., Enescu, C., Durrant, T., De Rigo, D., CaudulLO, G., 2016. Quercus frainetto in Europe: distribution, habitat, usage and threats. In European atlas of forest tree species. Luxembourg: Publication Office of the European Union. $150 \mathrm{p}$.

Perez, D., Kanninen, M., 2003. Provisional equations for estimating total and merchantable volume of Tectona grandis trees in Costa Rica. Forests, Trees and Livelihoods, 13: 345-359.

SchelhaAs, M.J., NabuURs, G.J., Jans, W.W.P., Moors, E.J., SABATÉ, S., DAAMEN, W.P., 2002. Converging estimates of the forest carbon sink: a comparison of the carbon sink of Scots pine forest in The Netherlands as presented by the eddy covariance and the forest inventory method. Alterra-rapport, 631. Wageningen: Alterra, Green World Research. 44 p.

Schumacher, F., Hall, F., 1933. Logarithm expression of timber tree volume. Journal of Agriculture Research, 47: 719-734.

Spanos, I., Meliadis, I., Platis, P., Mantzanas, K., Samara, T., Meliadis, M., 2015. Forest land ownership change in Greece. COST Action FP1201 FACESMAP Country Report. Vienna: European Forest Institute Central-East and South-East European Regional Office. 31 p. [online]. [cit. 2021-11-03]. https://facesmap.boku.ac.at/library/ FP1201_Country\%20Report_GREECE.pdf

Stolariková, R., Šálek, L., Zahradník, D., Dragoun, L., Jeřábková, L., Marušák, R., Merganič, J., 2014. Comparison of tree volume equations for small-leaved lime (Tilia cordata Mill.) in the Czech Republic. Scandinavian Journal of Forest Research, 29 (8): 757-763. https://doi. org/10.1080/02827581.2014.980316 
Strid, A., TAN, K., 1997. Flora Hellenica. Vol. 1. Konigstein: Koeltz Scientific Books. xxxvi, 547 p.

Tsitsoni, T.K., 2016. Greece. In Vidal, C., Alberdi, I., Hernández Mateo, L., Redmond, J. (eds). National forest inventories. Cham: Springer, p. 423-437. https://doi. org/10.1007/978-3-319-44015-_22

Vibrans, A.C., Moser, P., Oliveira, L.Z., De MaÇaneiro, J.P., 2015. Generic and specific stem volume models for three subtropical forest types in southern Brazil. Annals of Forest Science, 72: 865-874. https://doi.org/10.1007/ s13595-015-0481-x
Zianis, D., Muukkonen, P., MäkipäÄ, R., Mencuccini, M., 2005. Biomass and stem volume equations for tree species in Europe. Silva Fennica Monographs 4. Helsinki: Finnish Society of Forest Science. 63 p.

Zuur, A.F., Leno, E.N., Walker, N.J., Saveliev, A.A., SMith, G.M., 2009. Mixed effects models and extensions in ecology with $R$. New York, NY: Springer. 574 p.

Received December 10, 2020 Accepted April 26, 2021 